\title{
Produksi Tomat Cherry dan Tomat Beef dengan Sistem Hidroponik di Perusahaan Amazing Farm, Bandung
}

\section{Production of Cherry Tomato and Beef Tomato Hydroponics System at Amazing Farm, Bandung}

\author{
Eneng Fakhrunnisa, Juang Gema Kartika dan Sudarsono*
}

\author{
Departemen Agronomi dan Hortikultura, Fakultas Pertanian, Institut Pertanian Bogor \\ (Bogor Agricultural University), Jalan Meranti, Kampus IPB Darmaga, Bogor 16680,Indonesia \\ Telp.\&Faks.62-251-8629353 e-mail agronipb@indo.net.id \\ *Penulis untuk korespondensi : s_sudarsono@ymail.com
}

Disetujui 20 Agustus 2018 / Published online 3 September 2018

\begin{abstract}
Research at PT Amazing Farm was done February to Juny at 2017. The purpose of internship generally to learn and to improve technical skills and managerial in cherry tomato and beef tomato cultivation. The purpose of internship particular to evaluating the quantity and quality of cherry tomatoes and beef tomatoes with hydroponic system. The method used is direct method and indirect method. The direct method is carried out by following and observing technical activities in the cultivation of tomato in the field as well as interview. Indirect method is done by collecting supporting data from the company in the form of information general situation of the company, garden achive and literature study. The results showed the highest cherry tomato weights were at the 17th harvest of 166.53 grams for each plant and the highest beef tomato weights are at the time of the 11th harvest of 303.93 grams for each plant. Increasing age of harvest, decreasing of tomato weight and quality of tomato fruit. Tomato production reached $50 \%$ in the 19th harvest from 39 cherry tomatoes harvest and in the 17th harvest from 44 beef tomatoes harvest.
\end{abstract}

Key words: quality, production, weight, harvest

\begin{abstract}
ABSTRAK
Penelitian di Perusahaan Amazing Farm dilakukan bulan Februari hingga Juni 2017. Tujuan umum kegiatan penelitian yaitu mempelajari dan meningkatkan keterampilan teknis dan manajerial dalam budidaya tomat cherry dan tomat beef. Tujuan khusus dari kegiatan penelitian adalah mengevaluasi kuantitas dan kualitas tomat cherry dan tomat beef dengan sistem hidroponik. Metode yang digunakan adalah metode langsung dan metode tidak langsung. Metode langsung dilaksanakan dengan mengikuti dan mengamati kegiatan teknis dalam budidaya tomat di lapangan serta wawancara. Metode tidak langsung dilakukan dengan mengumpulkan data pendukung dari perusahaan berupa informasi keadaan umum perusahaan, arsip kebun dan studi pustaka. Hasil pengamatan menunjukkan bobot tomat cherry tertinggi yaitu saat panen ke-17 sebesar 166,53 gram/tanaman dan bobot tomat beef tertinggi yaitu saat panen ke-11 sebesar 303,93 gram/tanaman. Semakin bertambah umur panen, semakin menurun bobot tomat dan mutu tomat. Produksi tomat mencapai 50\% pada panen ke-19 dari 39 kali panen tomat cherry dan panen ke-17 dari 44 kali panen tomat beef.
\end{abstract}

Kata kunci: mutu, produksi, bobot, panen 


\section{PENDAHULUAN}

Sayuran merupakan sumber vitamin, mineral, dan serat yang diperlukan bagi kesehatan tubuh manusia. Seiring dengan meningkatnya kesadaran masyarakat terhadap pola hidup sehat menyebabkan minat masyarakat terhadap konsumsi sayuran semakin bertambah. Selain itu, permintaan akan komoditas sayuran mengalami peningkatan, hal ini berdasarkan data Dirjen Hortikultura (2010), pada tahun 2008 konsumsi sayuran masyarakat Indonesia sebesar 41,32 kilogram per kapita per tahun meningkat pada tahun 2009 menjadi 43,5 kilogram per kapita per tahun. Meskipun demikian, tingkat konsumsi sayuran di Indonesia masih di bawah standar. Standar konsumsi sayuran di Indonesia berdasarkan anjuran Food and Agriculture Organization yaitu $75 \mathrm{~kg}$ per kapita per tahun (FAO, 2010).

Produksi tomat di Indonesia tahun 2013 mencapai 992.780 ton (Dirjen hortikultura, 2015), tetapi permintaan pasar terhadap tomat pada tahun tersebut belum sepenuhnya terpenuhi sehingga Indonesia mengimpor tomat sebesar 11 ton (Pusdatin, 2014). Menurut data Dirjen Hortikultura (2015), produksi tomat di Indonesia pada tahun 2014 dan tahun 2015 mengalami penurunan masing-masing sebesar $7,74 \%$ dan $4,17 \%$. Selain itu, kebutuhan produksi tomat belum dapat diimbangi karena nilai rata-rata produktivitasnya sebesar 15,75 ton $\mathrm{ha}^{-1}$ masih tergolong rendah dibandingkan dengan potensi produktivitasnya, yaitu $45,7-80,0$ ton $\mathrm{ha}^{-1}$ (Kementan, 2012). Terjadinya penurunan produksi tomat di Indonesia disebabkan karena semakin sempitnya lahan pertanian yang subur dan adanya konversi lahan pertanian menjadi non pertanian, seperti di Jawa Barat pada tahun 2014 terjadi penurunan luas lahan pertanian seluas 337.817,82 ha (Pusdatin, 2015). Hal ini menyebabkan kuantitas dan kualitas tomat masih rendah sehingga belum dapat memenuhi kebutuhan konsumen.

Pengelolaan produksi tomat dengan pengefisienan lahan dan modifikasi teknologi dapat dilakukan melalui sistem hidroponik. Hasil panen yang dapat diperoleh dari sistem hidroponik yaitu lima sampai sepuluh kali lipat lebih banyak daripada hasil panen yang diperoleh dengan sistem budidaya konvensional (Harun, 1989). Pernyataan ini diperkuat oleh Smith (2005), yang menyatakan bahwa tomat yang dihasilkan dengan sistem hidroponik sebesar 55,6 $\mathrm{kg} \mathrm{m}{ }^{-2}$ dengan total grade A sebesar $95 \%$. Sedangkan tomat yang dihasilkan secara konvensional sebesar $5,9 \mathrm{~kg} \mathrm{~m}^{-2}$ dengan total grade A sebesar $80 \%$. Oleh karena itu, menurut Indriasti (2013) menanam sayuran buah secara hidroponik lebih menguntungkan karena mutu produk yang dihasilkan lebih berkualitas dan aman dari residu pestisida dan bahan kimia. Sistem budidaya hidroponik belum banyak dikembangkan di Indonesia, sistem budidaya ini perlu dipelajari lebih lanjut karena memiliki banyak kelebihan. Beberapa kelebihannya yaitu produksi tanaman lebih tinggi, serangan hama dan penyakit berkurang, dan hasil panen yang kontinu. Tanaman yang dibudidayakan secara hidroponik pertumbuhannya lebih cepat dan pemakaian pupuk yang digunakan lebih efisien. Metode kerja yang digunakan dalam membudidayakan tanaman secara hidroponik sudah distandarisasi sehingga lebih memudahkan pekerjaan dan penggunaan tenaga kerja kebun yang lebih efisien (Lingga, 1999).

Permasalahan penting budidaya sayuran selain karena faktor keterbatasan lahan, yaitu penentuan umur panen. Perbedaan umur panen tanaman tomat dapat mempengaruhi produktivitas dan mutu tomat. Tomat yang dipanen sebelum matang akan menghasilkan mutu yang kurang baik serta proses pematangan yang kurang sempurna. Penundaan waktu panen akan meningkatkan kepekaan buah terhadap proses pembusukan, sehingga mutu dan nilai jualnya rendah (Pantastico, 1989). Penentuan waktu panen dan cara panen yang tidak tepat dapat mengurangi hasil panen sekitar 24\% dengan jumlah kehilangan hasil setelah panen $11,9 \%$ dan kehilangan hasil setelah penyimpanan sebesar $12,1 \%$ (Rapusas, 2006). Tujuan umum dari kegiatan penelitian adalah untuk mempelajari dan meningkatkan keterampilan teknis dan manajerial dalam budidaya tomat cherry dan tomat beef dengan sistem hidroponik. Sedangkan tujuan khusus dari kegiatan penelitian adalah mengevaluasi kuantitas dan kualitas tomat cherry dan tomat beef pada setiap umur panen dengan sistem hidroponik substrat.

\section{METODE}

Kegiatan penelitian dilaksanakan di Amazing Farm, Jalan Cisaroni, Desa Cikahuripan, Kecamatan Lembang, Kabupaten Bandung. Kegiatan penelitian dilakukan mulai dari bulan Februari sampai dengan Juni 2017. Metode pelaksanaan penelitian menggunakan metode langsung dan metode tidak langsung. Metode langsung dilaksanakan dengan mengikuti dan mengamati kegiatan teknis dalam budidaya tomat di lapangan serta wawancara. Metode tidak langsung dilakukan dengan mengumpulkan data 
pendukung dari perusahaan berupa informasi keadaan umum perusahaan, arsip kebun dan studi pustaka. Pelaksanaan metode langsung yaitu aspek khusus.

Aspek khusus dilakukan dengan mengevaluasi kuantitas dan kualitas tomat cherry dan tomat beef, mengukur jumlah dan bobot tomat pada setiap pemanenan, serta mengukur tingkat produktivitasnya. Pengamatan yang dilakukan meliputi kegiatan budidaya tanaman tomat hingga kegiatan panen dan pascapanen selama di perusahaan. Masa panen berlangsung sekitar 3 bulan, dengan interval panen dua hari sekali. Pengamatan dilakukan pada 15 tanaman contoh yang ditentukan secara acak.

\section{Pengamatan dan Pengumpulan Data}

Pengumpulan data dalam kegiatan penelitian berasal dari dua sumber data, yaitu data primer dan sekunder. Data primer diperoleh dengan melakukan pengamatan langsung terhadap semua kegiatan yang berkaitan dengan aspek teknis dari kegiatan di lapangan, wawancara dengan karyawan, mandor, dan supervisor serta dengan mengamati fase generatif tanaman tomat. Pengamatan generatif tanaman meliputi: umur berbunga dan umur panen. Pengamatan pada aspek pemanenan meliputi: panjang buah, diameter buah, jumlah buah per tandan, bobot panen, penghitungan satuan panas (heat unit) greenhouse. Data sekunder diperoleh dari arsip

Tabel 1. Keragaan tomat cherry perusahaan dan studi pustaka sesuai dengan aspek penelitian. Data sekunder yang diperoleh dari perusahaan meliputi data produktivitas tanaman, kondisi perusahaan, denah greenhouse, data struktur organisasi, dan data pendukung lainnya. Analisis Data dan Informasi

Data yang diperoleh diolah dengan menggunakan analisis kuantitatif dan analisis deskriptif. Analisis kuantitatif dilakukan pada data primer dan sekunder yang bersifat kuantitatif dengan menggunakan nilai rata-rata, persentase, dan uji t-student taraf $\alpha=5 \%$. Data dibagi menjadi empat bagian waktu panen untuk mengamati laju produksi tomat berdasarkan tingkat kualitas dan kuantitas tomat. Analisis deskriptif dilakukan pada data yang bersifat kualitatif dan kuantitatif. Analisis kualitatif digunakan untuk menganalisis aspek teknis dan aspek manajerial.

\section{HASIL DAN PEMBAHASAN}

\section{Aspek Khusus}

Tomat Cherry . Panen tomat dilakukan berdasarkan panen warna. Perubahan warna digunakan menjadi suatu indikator kematangan tomat. Keragaan tomat cherry yang dipanen dapat dilihat pada Tabel 1. Standar warna tomat cherry yang digunakan perusahaan saat panen sebagian besar pada skala warna pink dan turning. Berdasarkan hasil pengamatan umur berbunga tomat cherry yaitu 49 HST.

\begin{tabular}{|c|c|}
\hline Kriteria & Keragaan buah \\
\hline Panjang buah $(\mathrm{cm})$ & 2,37 \\
\hline Diameter buah $(\mathrm{cm})$ & 2,53 \\
\hline Bobot per buah (gram) & 9,50 \\
\hline Jumlah buah per tandan (buah) & 9,16 \\
\hline Jumlah tandan produktif (tandan) & 13,00 \\
\hline Bobot buah per tandan $(\mathrm{g})$ & 87,01 \\
\hline Bobot panen per tanaman $(\mathrm{g})$ & $2.262,20$ \\
\hline
\end{tabular}




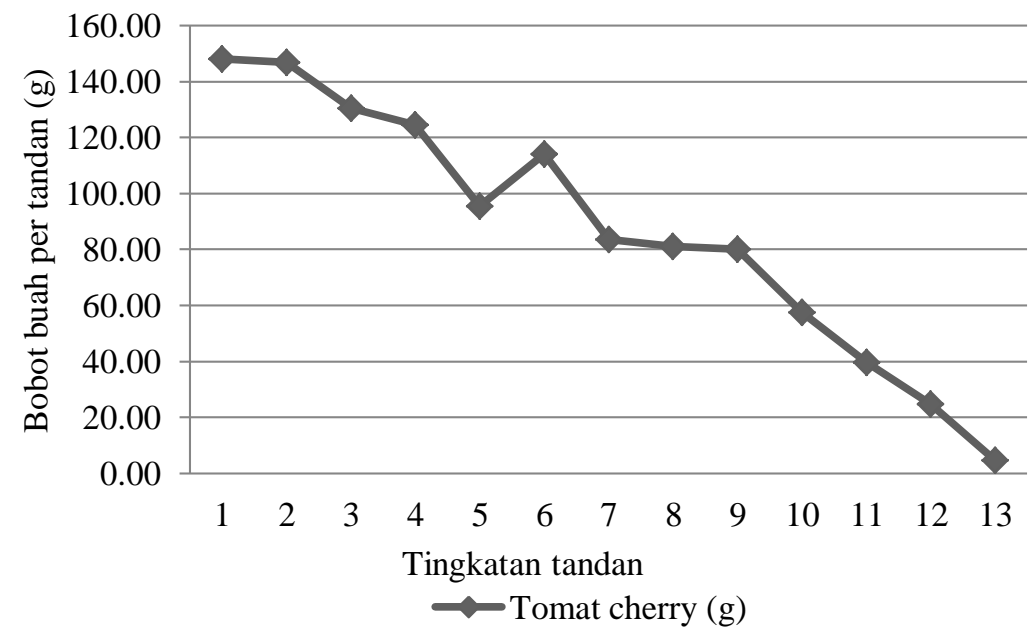

a

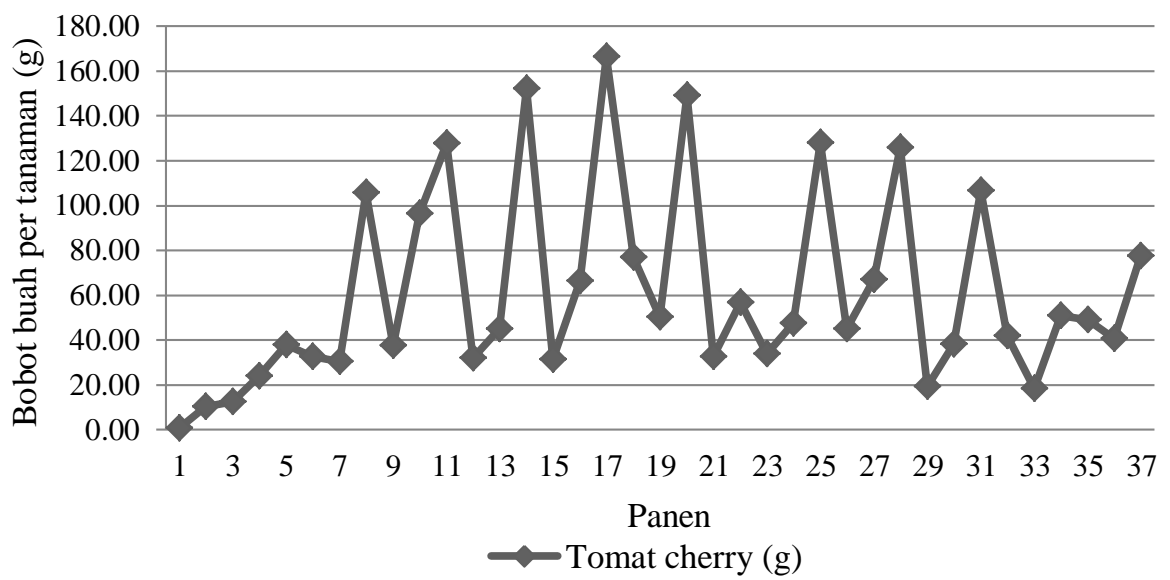

a. Bobot tomat cherry per tandan

b

b.Bobot tomat cherry per tanaman

Gambar 1. Bobot panen tomat cherry

Tingkatan tandan mempengaruhi bobot hasil panen yang didapat. Bobot tomat cherry tertinggi terdapat pada tandan pertama sebesar 148,20 gram. Semakin tinggi tandan maka bobot panen tomat semakin menurun, bobot rata-rata panen terendah terdapat pada tandan ke-13 sebesar 4,60 gram (Gambar 1a). Dari Gambar 1b dapat dilihat hasil panen tertinggi terjadi saat panen ke-17 yaitu dengan bobot rata-rata sebesar 166,53 gram per tanaman. Total produksi pada panen terakhir meningkat kembali dikarenakan adanya panen bongkar.

Tabel 2 menunjukkan semakin bertambah umur panen, semakin menurun bobot tomat dan mutu tomat. Berdasarkan data perusahaan (2017), grade A yang dihasilkan pada awal masa panen tomat cherry mencapai $100 \%$, tetapi pada panen ke-11 persentase grade A rendah yaitu 36,51\%, disebabkan adanya tomat yang terlambat dipanen sehingga dapat menurunkan kualitas buah. Penurunan kualitas buah menyebabkan total produksi grade B terbesar terjadi pada panen ke11 yaitu sebesar $58,85 \%$. Capaian produksi tomat cherry pada masa panen tengah atau panen ke-20 lebih dari $50 \%$ yaitu sebesar $56,93 \%$. Hal ini mempengaruhi capaian produksi pada masa panen kuartil selanjutnya yang diperkirakan mencapai $75 \%$ produksi pada panen ke-30, tetapi produksi yang dihasilkan melebihi dugaan yaitu sebesar $83,75 \%$. Perolehan hasil panen ke-33 persentase total produksi mulai mengecil. Hasil tersebut menunjukkan bahwa kecepatan produksi tomat semakin menurun pada akhir masa panen. Berdasarkan penelitian Putri et al. (2014), semakin lama umur panen tanaman maka bobot buah total per tanaman juga akan semakin rendah. 
Tabel 2.Bobot panen tomat cherry berdasarkan grading

\begin{tabular}{|c|c|c|c|c|c|c|c|c|c|}
\hline Panen & $\begin{array}{l}\text { Grade } \\
\text { A (kg) }\end{array}$ & $\begin{array}{c}\text { Grade } \\
\text { A/total } \\
(\%)\end{array}$ & $\begin{array}{l}\text { Grade } \\
\mathrm{B}(\mathrm{kg})\end{array}$ & $\begin{array}{c}\text { Grade } \\
\text { B/total } \\
(\%)\end{array}$ & $\begin{array}{c}\text { Reject } \\
(\mathrm{kg})\end{array}$ & $\begin{array}{c}\text { Rejectl } \\
\text { total } \\
(\%)\end{array}$ & $\begin{array}{l}\text { Total } \\
(\mathrm{kg})\end{array}$ & $\begin{array}{c}\text { Total } \\
\text { Produksi } \\
(\%)\end{array}$ & $\begin{array}{c}\text { Capaian } \\
\text { Produksi } \\
(\%)\end{array}$ \\
\hline 1 & 5,25 & 100,00 & 0,00 & 0,00 & 0,00 & 0,00 & 5,25 & 0,18 & 0,18 \\
\hline 2 & 14,50 & 100,00 & 0,00 & 0,00 & 0,00 & 0,00 & 14,50 & 0,51 & 0,69 \\
\hline 3 & 20,00 & 99,01 & 0,00 & 0,00 & 0,20 & 0,99 & 20,20 & 0,71 & 1,39 \\
\hline 4 & 33,25 & 97,08 & 0,00 & 0,00 & 1,00 & 2,92 & 34,25 & 1,20 & 2,59 \\
\hline 5 & 48,00 & 98,26 & 0,00 & 0,00 & 0,85 & 1,74 & 48,85 & 1,71 & 4,30 \\
\hline 6 & 37,25 & 97,51 & 0,00 & 0,00 & 0,95 & 2,49 & 38,20 & 1,33 & 5,63 \\
\hline 7 & 21,00 & 39,11 & 31,30 & 58,29 & 1,40 & 2,61 & 53,70 & 1,88 & 7,51 \\
\hline 8 & 109,50 & 96,56 & 3,50 & 3,09 & 0,40 & 0,35 & 113,40 & 3,96 & 11,47 \\
\hline 9 & 46,75 & 97,60 & 0,00 & 0,00 & 1,15 & 2,40 & 47,90 & 1,67 & 13,14 \\
\hline 10 & 66,25 & 59,47 & 42,75 & 38,38 & 2,40 & 2,15 & 111,40 & 3,89 & 17,03 \\
\hline 11 & 53,50 & 36,51 & 86,25 & 58,85 & 6,80 & 4,64 & 146,55 & 5,12 & 22,14 \\
\hline 12 & 28,75 & 82,14 & 5,00 & 14,29 & 1,25 & 3,57 & 35,00 & 1,22 & 23,37 \\
\hline 13 & 61,75 & 85,76 & 10,25 & 14,24 & 0,00 & 0,00 & 72,00 & 2,51 & 25,88 \\
\hline 14 & 85,25 & 44,99 & 104,00 & 54,88 & 0,25 & 0,13 & 189,50 & 6,62 & 32,50 \\
\hline 15 & 35,75 & 65,30 & 17,00 & 31,05 & 2,00 & 3,65 & 54,75 & 1,91 & 34,41 \\
\hline 16 & 57,25 & 81,49 & 10,00 & 14,23 & 3,00 & 4,27 & 70,25 & 2,45 & 36,86 \\
\hline 17 & 175,75 & 81,46 & 35,00 & 16,22 & 5,00 & 2,32 & 215,75 & 7,53 & 44,40 \\
\hline 18 & 94,50 & 87,10 & 10,00 & 9,22 & 4,00 & 3,69 & 108,50 & 3,79 & 48,18 \\
\hline 19 & 66,50 & 74,55 & 21,00 & 23,54 & 1,70 & 1,91 & 89,20 & 3,11 & 51,30 \\
\hline 20 & 151,25 & 93,80 & 5,00 & 3,10 & 5,00 & 3,10 & 161,25 & 5,63 & 56,93 \\
\hline 21 & 36,50 & 84,69 & 2,00 & 4,64 & 4,60 & 10,67 & 43,10 & 1,50 & 58,43 \\
\hline 22 & 60,00 & 89,02 & 6,00 & 8,90 & 1,40 & 2,08 & 67,40 & 2,35 & 60,79 \\
\hline 23 & 83,75 & 83,13 & 12,00 & 11,91 & 5,00 & 4,96 & 100,75 & 3,52 & 64,31 \\
\hline 24 & 38,75 & 71,76 & 10,00 & 18,52 & 5,25 & 9,72 & 54,00 & 1,89 & 66,19 \\
\hline 25 & 64,00 & 93,57 & 0,00 & 0,00 & 4,40 & 6,43 & 68,40 & 2,39 & 68,58 \\
\hline 26 & 136,25 & 92,28 & 3,00 & 2,03 & 8,40 & 5,69 & 147,65 & 5,16 & 73,74 \\
\hline 27 & 65,00 & 87,84 & 8,00 & 10,81 & 1,00 & 1,35 & 74,00 & 2,58 & 76,32 \\
\hline 28 & 47,75 & 94,09 & 1,00 & 1,97 & 2,00 & 3,94 & 50,75 & 1,77 & 78,09 \\
\hline 29 & 110,00 & 88,14 & 6,00 & 4,81 & 8,80 & 7,05 & 124,80 & 4,36 & 82,45 \\
\hline 30 & 31,50 & 84,68 & 0,00 & 0,00 & 5,70 & 15,32 & 37,20 & 1,30 & 83,75 \\
\hline 31 & 25,75 & 90,83 & 0,00 & 0,00 & 2,60 & 9,17 & 28,35 & 0,99 & 84,74 \\
\hline 32 & 95,50 & 96,76 & 0,00 & 0,00 & 3,20 & 3,24 & 98,70 & 3,45 & 88,18 \\
\hline 33 & 37,50 & 93,52 & 0,00 & 0,00 & 2,60 & 6,48 & 40,10 & 1,40 & 89,58 \\
\hline 34 & 19,75 & 87,39 & 1,50 & 6,64 & 1,35 & 5,97 & 22,60 & 0,79 & 90,37 \\
\hline 35 & 28,75 & 77,18 & 5,50 & 14,77 & 3,00 & 8,05 & 37,25 & 1,30 & 91,67 \\
\hline
\end{tabular}


Tabel 2. (Lanjutan)

\begin{tabular}{cccccccccc}
\hline Panen & $\begin{array}{c}\text { Grade } \\
\text { A }(\mathrm{kg})\end{array}$ & $\begin{array}{c}\text { Grade } \\
\text { A/total } \\
(\%)\end{array}$ & $\begin{array}{c}\text { Grade } \\
\mathrm{B}(\mathrm{kg})\end{array}$ & $\begin{array}{c}\text { Grade } \\
\text { B/total } \\
(\%)\end{array}$ & $\begin{array}{c}\text { Reject } \\
(\mathrm{kg})\end{array}$ & $\begin{array}{c}\text { Reject/ } \\
\text { total } \\
(\%)\end{array}$ & $\begin{array}{c}\text { Total } \\
(\mathrm{kg})\end{array}$ & $\begin{array}{c}\text { Total } \\
\text { Produksi } \\
(\%)\end{array}$ & $\begin{array}{c}\text { Capaian } \\
\text { Produksi } \\
(\%)\end{array}$ \\
\hline 36 & 40,00 & 86,96 & 6,00 & 13,04 & 0,00 & 0,00 & 46,00 & 1,61 & 93,28 \\
37 & 30,00 & 80,43 & 3,00 & 8,04 & 4,30 & 11,53 & 37,30 & 1,30 & 94,58 \\
38 & 48,00 & 69,16 & 18,00 & 25,94 & 3,40 & 4,90 & 69,40 & 2,42 & 97,01 \\
39 & 80,25 & 93,59 & 4,00 & 4,66 & 1,50 & 1,75 & 85,75 & 2,99 & 100,00 \\
\hline Total & 2291,00 & 80,00 & 467,05 & 16,31 & 105,85 & 3,70 & 2863,90 & 100,00 & \\
\hline
\end{tabular}

Keterangan: Grade A dan grade $\mathrm{B}=$ layak pasar; reject= tidak layak pasar

\section{Tomat Beef}

Pemanenan tomat tidak dapat dilakukan sekaligus, tetapi harus dilakukan berkali-kali sesuai dengan kematangan tomat. Keragaan tomat beef yang dipanen dapat dilihat pada Tabel 3 .

Tabel 3. Keragaan tomat beef
Standar warna tomat beef yang digunakan perusahaan saat panen sebagian besar pada skala warna breaker, turning, dan pink. Berdasarkan hasil pengamatan umur berbunga tomat beef yaitu 28 HST.

\begin{tabular}{lc}
\hline \multicolumn{1}{c}{ Kriteria } & Keragaan buah \\
\hline Panjang buah $(\mathrm{cm})$ & 5,44 \\
Diameter buah $(\mathrm{cm})$ & 7,01 \\
Bobot/buah $(\mathrm{gram})$ & 160,56 \\
Jumlah buah per tandan (buah) & 2,47 \\
Jumlah tandan produktif (tandan) & 12,00 \\
Bobot buah per tandan $(\mathrm{g})$ & 396,04 \\
Bobot panen per tanaman $(\mathrm{g})$ & $4.752,53$ \\
\hline
\end{tabular}

Tomat beef dapat menghasilkan 12 tandan tomat dengan bobot tomat beef tertinggi terdapat pada tandan pertama sebesar 729,73 gram (Gambar 2a). Semakin tinggi tandan, bobot panen tomat semakin menurun. Bobot rata-rata panen terendah terdapat pada tandan ke-12 sebesar 63,07 gram. Penyerapan unsur hara menurun seiring dengan bertambahnya umur tanaman pada akhir masa panen sehingga semakin rendah produktivitasnya. Hasil panen tertinggi tomat beef terjadi saat panen ke-11 yaitu dengan total bobot rata-rata sebesar 303,93 gram per tanaman (Gambar 2b). Hasil panen terendah terjadi pada masa awal panen karena pada masa awal panen sebagian besar tanaman masih dalam masa pengisian buah. Produksi tomat beef pada panen akhir atau panen ke-37 mengalami peningkatan yang signifikan. Hal ini dikarenakan adanya panen bongkar atau panen hijau.

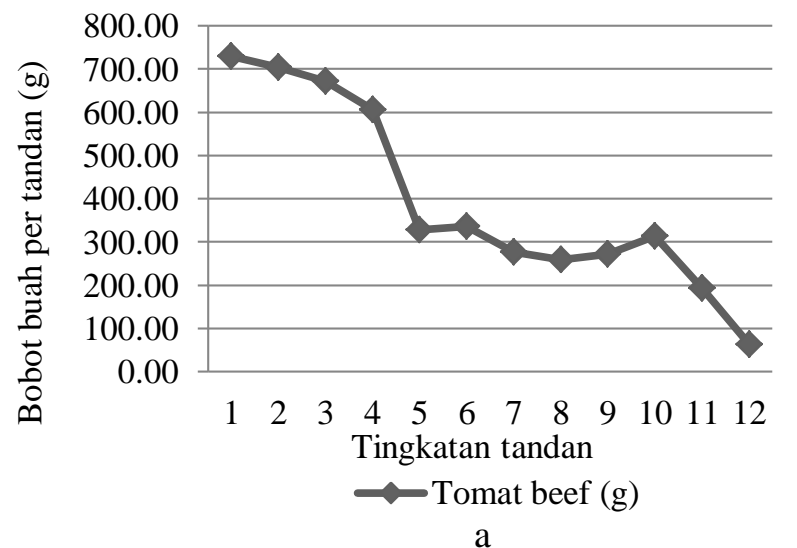

a. Bobot tomat beef per tandan

b. Bobot tomat beef per tanaman

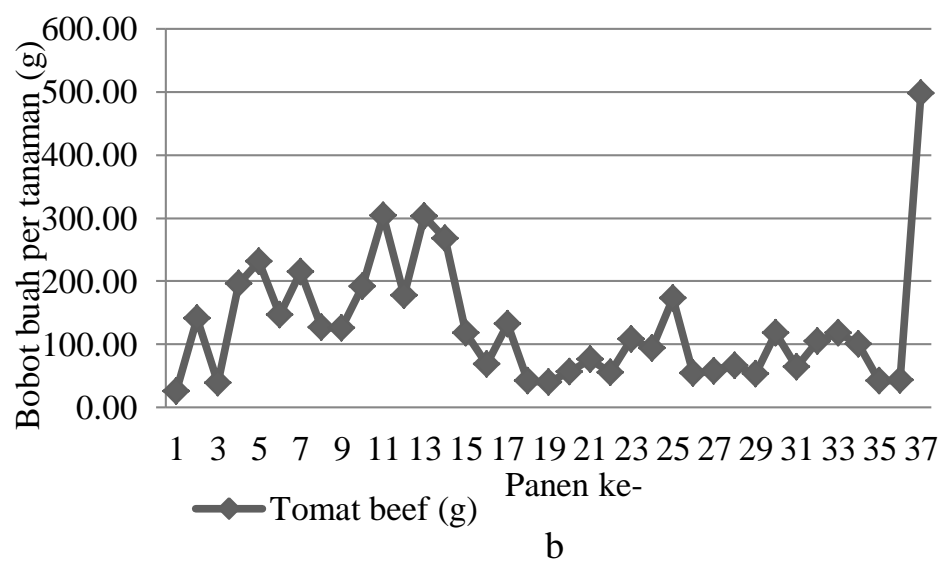

Gambar 2. Bobot panen tomat beef 
Berdasarkan data perusahaan pada Tabel 4, diperoleh persentase grade A terbesar sebelum masa panen kuartil pertama pada panen ke-10 yaitu sebesar $97,44 \%$. Menuju masa akhir panen perolehan persentase grade A relatif menurun sehingga grade $\mathrm{B}$ dan $\mathrm{C}$ relatif meningkat terutama mulai panen ke-39. Capaian produksi tomat beef pada masa kuartil kedua atau panen ke-22 lebih dari 50\% yaitu sebesar 63,52\%. Hal ini diduga dapat mempengaruhi capaian produksi pada masa panen kuartil selanjutnya yang diperkirakan mencapai $75 \%$ produksi pada panen ke-33, produksi yang dihasilkan melebihi dugaan yaitu sebesar $81,91 \%$. Total produksi tomat beef pada masa panen akhir atau panen ke-44 meningkat karena adanya panen bongkar.

Tabel 4. Bobot panen tomat beef berdasarkan grading

\begin{tabular}{|c|c|c|c|c|c|c|c|c|c|c|c|}
\hline Panen & $\begin{array}{l}\text { Grade } \\
\text { A (kg) }\end{array}$ & $\begin{array}{c}\text { Grade } \\
\text { A/total } \\
(\%)\end{array}$ & $\begin{array}{l}\text { Grade } \\
\mathrm{B}(\mathrm{kg})\end{array}$ & $\begin{array}{c}\text { Grade } \\
\text { B/total } \\
(\%)\end{array}$ & $\begin{array}{l}\text { Grade } \\
\mathrm{C}(\mathrm{kg})\end{array}$ & $\begin{array}{c}\text { Grade } \\
\text { C/total } \\
(\%)\end{array}$ & $\begin{array}{l}\text { Grade } \\
\mathrm{D}(\mathrm{kg})\end{array}$ & $\begin{array}{c}\text { Grade } \\
\text { D/total } \\
(\%)\end{array}$ & $\begin{array}{c}\text { Reject/ } \\
\text { total } \\
(\%)\end{array}$ & $\begin{array}{c}\text { Total } \\
\text { Produksi } \\
(\%)\end{array}$ & $\begin{array}{c}\text { Capaian } \\
\text { Produksi } \\
(\%)\end{array}$ \\
\hline 2 & 50 & 75,76 & 10 & 15,15 & 2,0 & 3,03 & 0,0 & 0,00 & 6,06 & 0,62 & 0,70 \\
\hline 3 & 150 & 89,29 & 16 & 9,52 & 0,0 & 0,00 & 0,0 & 0,00 & 1,19 & 1,57 & 2,27 \\
\hline 4 & 221 & 90,57 & 19 & 7,79 & 3,0 & 1,23 & 0,0 & 0,00 & 0,41 & 2,28 & 4,54 \\
\hline 5 & 310 & 89,99 & 31 & 9,00 & 3,5 & 1,02 & 0,0 & 0,00 & 0,00 & 3,22 & 7,76 \\
\hline 6 & 470 & 86,16 & 63 & 11,55 & 5,5 & 1,01 & 5,0 & 0,92 & 0,37 & 5,10 & 12,86 \\
\hline 7 & 324 & 86,63 & 36 & 9,63 & 4,0 & 1,07 & 10,0 & 2,67 & 0,00 & 3,49 & 16,35 \\
\hline 8 & 390 & 75,00 & 50 & 9,62 & 5,0 & 0,96 & 70,0 & 13,46 & 0,96 & 4,86 & 21,21 \\
\hline 9 & 550 & 86,61 & 57 & 8,98 & 5,0 & 0,79 & 15,0 & 2,36 & 1,26 & 5,93 & 27,14 \\
\hline 10 & 190 & 97,44 & 5 & 2,56 & 0,0 & 0,00 & 0,0 & 0,00 & 0,00 & 1,82 & 28,96 \\
\hline 11 & 139 & 70,74 & 35 & 17,81 & 2,5 & 1,27 & 15,0 & 7,63 & 2,54 & 1,84 & 30,80 \\
\hline 12 & 280 & 74,89 & 48 & 12,84 & 2,9 & 0,78 & 20,0 & 5,35 & 6,15 & 3,49 & 34,29 \\
\hline 13 & 389 & 81,55 & 56 & 11,74 & 0,0 & 0,00 & 20,0 & 4,19 & 2,52 & 4,46 & 38,75 \\
\hline 14 & 340 & 81,34 & 52 & 12,44 & 10,0 & 2,39 & 10,0 & 2,39 & 1,44 & 3,90 & 42,65 \\
\hline 15 & 295 & 80,60 & 45 & 12,30 & 2,0 & 0,55 & 20,0 & 5,46 & 1,09 & 3,42 & 46,07 \\
\hline 16 & 270 & 72,33 & 47 & 12,59 & 3,3 & 0,88 & 30,0 & 8,04 & 6,16 & 3,49 & 49,56 \\
\hline 17 & 396 & 73,43 & 104 & 19,28 & 9,3 & 1,72 & 20,0 & 3,71 & 1,85 & 5,04 & 54,60 \\
\hline 18 & 250 & 77,14 & 46 & 14,19 & 4,1 & 1,27 & 20,0 & 6,17 & 1,23 & 3,03 & 57,63 \\
\hline 19 & 170 & 66,38 & 70 & 27,33 & 3,1 & 1,21 & 0,0 & 0,00 & 5,08 & 2,39 & 60,02 \\
\hline 20 & 110 & 62,86 & 43 & 24,57 & 5,0 & 2,86 & 0,0 & 0,00 & 9,71 & 1,63 & 61,65 \\
\hline 21 & 70 & 68,90 & 28 & 27,56 & 1,6 & 1,57 & 0,0 & 0,00 & 1,97 & 0,95 & 62,60 \\
\hline 22 & 60 & 60,91 & 29 & 29,44 & 6,5 & 6,60 & 0,0 & 0,00 & 3,05 & 0,92 & 63,52 \\
\hline 23 & 80 & 46,89 & 45 & 26,38 & 9,6 & 5,63 & 0,0 & 0,00 & 21,10 & 1,59 & 65,12 \\
\hline 24 & 95 & 67,14 & 33 & 23,32 & 7,5 & 5,30 & 0,0 & 0,00 & 4,24 & 1,32 & 66,44 \\
\hline 25 & 120 & 62,02 & 54 & 27,91 & 6,5 & 3,36 & 0,0 & 0,00 & 6,72 & 1,81 & 68,25 \\
\hline 26 & 150 & 56,84 & 82 & 31,07 & 19,9 & 7,54 & 0,0 & 0,00 & 4,55 & 2,47 & 70,71 \\
\hline 27 & 170 & 65,54 & 61 & 23,52 & 7,4 & 2,85 & 10,0 & 3,86 & 4,24 & 2,42 & 73,14 \\
\hline 28 & 170 & 75,19 & 46 & 20,34 & 5,1 & 2,26 & 0,0 & 0,00 & 2,21 & 2,11 & 75,25 \\
\hline 29 & 230 & 75,78 & 44 & 14,50 & 8,5 & 2,80 & 0,0 & 0,00 & 6,92 & 2,84 & 78,08 \\
\hline 30 & 85 & 71,85 & 29 & 24,51 & 3,3 & 2,79 & 0,0 & 0,00 & 0,85 & 1,11 & 79,19 \\
\hline 31 & 43 & 52,44 & 22 & 26,83 & 5,0 & 6,10 & 5,0 & 6,10 & 8,54 & 0,77 & 79,95 \\
\hline 32 & 100 & 68,68 & 31 & 21,29 & 5,6 & 3,85 & 0,0 & 0,00 & 6,18 & 1,36 & 81,31 \\
\hline 33 & 44 & 69,29 & 15 & 23,62 & 1,5 & 2,36 & 0,0 & 0,00 & 4,72 & 0,59 & 81,91 \\
\hline 34 & 25 & 45,37 & 20 & 36,30 & 4,1 & 7,44 & 0,0 & 0,00 & 10,89 & 0,51 & 82,42 \\
\hline 35 & 37 & 43,79 & 32 & 37,87 & 5,5 & 6,51 & 0,0 & 0,00 & 11,83 & 0,79 & 83,21 \\
\hline 36 & 70 & 52,24 & 46 & 34,33 & 8,0 & 5,97 & 7,5 & 5,60 & 1,87 & 1,25 & 84,46 \\
\hline 37 & 182 & 65,35 & 79 & 28,37 & 12,0 & 4,31 & 0,0 & 0,00 & 1,97 & 2,60 & 87,07 \\
\hline 38 & 190 & 66,29 & 65 & 22,68 & 17,3 & 6,04 & 10,0 & 3,49 & 1,50 & 2,68 & 89,74 \\
\hline 39 & 104 & 59,43 & 55 & 31,43 & 10,0 & 5,71 & 0,0 & 0,00 & 3,43 & 1,63 & 91,38 \\
\hline 40 & 60 & 48,78 & 46 & 37,40 & 8,0 & 6,50 & 0,0 & 0,00 & 7,32 & 1,15 & 92,53 \\
\hline 41 & 93 & 49,08 & 78 & 41,16 & 14,5 & 7,65 & 0,0 & 0,00 & 2,11 & 1,77 & 94,30 \\
\hline 42 & 80 & 60,84 & 43 & 32,70 & 7,5 & 5,70 & 0,0 & 0,00 & 0,76 & 1,23 & 95,53 \\
\hline 43 & 38 & 49,35 & 30 & 38,96 & 0,0 & 0,00 & 0,0 & 0,00 & 11,69 & 0,72 & 96,24 \\
\hline 44 & 0 & 0,00 & 0 & 0,00 & 0,0 & 0,00 & 402,0 & 100,00 & 0,00 & 3,76 & 100,00 \\
\hline Total & 7596 & 70,96 & 1848 & 17,26 & 245,1 & 2,29 & 689,5 & 6,44 & 3,04 & 100,00 & \\
\hline
\end{tabular}

Keterangan: Grade A, B, C, dan D= layak pasar; reject= tidak layak pasar

Total Bobot Panen Tomat Cherry dan Tomat Beef

Hasil pengamatan pada Tabel 5 menunjukkan bahwa bobot panen tomat cherry dan tomat beef berbeda nyata dengan bobot panen standar. Bobot panen yang dihasilkan melebihi bobot panen standar. Umur panen tomat cherry 
adalah 65-152 HST dengan masa panen selama 2,90 bulan dan umur panen tomat beef adalah 77166 HST dengan masa panen selama 2,97 bulan. Semakin panjang masa panen, maka semakin bertambah pula bobot panen yang dihasilkan. Selain itu, penggunaan pupuk yang optimal dan kondisi lingkungan yang mendukung menyebabkan produksi tomat lebih tinggi. Menurut Wijayani dan Widodo (2005), kemampuan tomat untuk dapat menghasilkan buah sangat tergantung pada interaksi antara pertumbuhan tanaman dan kondisi lingkungannya.

Tabel 5. Bobot panen tomat di PT Amazing Farm

\begin{tabular}{lccccc}
\hline Komoditas & Masa panen (MST) & Bobot panen standar $(\mathrm{g})$ & Bobot panen $(\mathrm{g})$ & $\mathrm{P}$ value & $\operatorname{Pr}(>|\mathrm{t}|)$ \\
\hline Tomat cherry & 12 & 2.000 & $2.262,20 \pm 389,73$ & 0,010 & $*$ \\
Tomat beef & 12 & 4.000 & $4.752,53 \pm 1.272,90$ & 0,019 & $*$ \\
\hline
\end{tabular}

Keterangan: *= hasil uji-t pada baris yang sama menunjukkan hasil berbeda nyata pada taraf $\alpha=5 \%$

\section{Kehilangan Hasil}

Berdasarkan data tersebut total bobot panen tomat cherry mengalami kehilangan hasil sebesar $3.70 \%$ dan tomat beef sebesar $3,04 \%$ (Tabel 6). Persentase kehilangan hasil diperoleh dari tomat yang memiliki kriteria reject akibat pecah, memar, dan tidak sesuai ukuran.
Berdasarkan hasil pengamatan Prabawati (2011), tingkat kehilangan hasil tomat yang terjadi berkisar antara 0-16\%. Rendahnya tingkat kehilangan hasil ini disebabkan karena hasil panen dari bidang produksi memiliki mutu yang baik.

Tabel 6. Persentase kehilangan hasil panen tomat cherry dan tomat beef

\begin{tabular}{lccc}
\hline \multicolumn{1}{c}{ Komoditas } & Bobot panen $\mathrm{GH}^{-1}(\mathrm{~kg})$ & Bobot bersih $\mathrm{GH}^{-1}(\mathrm{~kg})$ & Kehilangan hasil \\
\hline Tomat cherry & $2.863,90$ & $2.758,00$ & $3,70 \%$ \\
Tomat beef & $10.704,40$ & $10.378,60$ & $3,04 \%$ \\
\hline
\end{tabular}

Sumber: Data perusahaan, 2017

\section{Heat Unit}

Menurut Syakur (2012), laju perkembangan tanaman terjadi bila suhu udara rata-rata harian melebihi suhu dasar. Rentang maksimum suhu dasar tanaman tomat yakni $10{ }^{\circ} \mathrm{C}$ (Perry et al., 1997). Suhu udara di dalam greenhouse berfluktuasi dari hari ke hari melebihi suhu dasar. Suhu udara rata-rata di dalam greenhouse yaitu $27^{\circ} \mathrm{C}$ dalam greenhouse tomat cherry dan $26^{\circ} \mathrm{C}$ dalam greenhouse tomat beef (Tabel 7). Satuan panas yang diperlukan dari mulai umur berbunga hingga panen akhir tercatat $1.785{ }^{\circ} \mathrm{C}$ hari pada tanaman tomat cherry dan $2.270{ }^{\circ} \mathrm{C}$ hari pada tanaman tomat beef.

Tabel 7. Heat unit masa generatif tanaman tomat

\begin{tabular}{lcccc}
\hline \multicolumn{1}{c}{ Komoditas } & Fase & Lama (hari) & Heat unit $\left({ }^{\circ} \mathrm{C}\right.$ hari) & RH (\%) \\
\hline Tomat cherry & UB-PA & 16 & 272 & 80 \\
& PA-PK & 89 & 1.513 & 79 \\
Jumlah & & 105 & 1.785 & 80 \\
Rata-rata & & & 78 \\
\hline Tomat beef & UB-PA & 46 & 765 & 73 \\
& PA-PK & 94 & 1.504 & 75 \\
Jumlah & & 140 & 2.270 & 75 \\
Rata-rata & & &
\end{tabular}

Keterangan: $\quad$ UB-PA adalah periode saat umur berbunga (UB) sampai panen awal (PA); PA-PK adalah periode saat panen awal (PA) sampai panen akhir (PK).

\section{Analisis Usahatani}

Satu siklus panen menghasilkan bobot bersih tomat sebesar $2.758,05 \mathrm{~kg}$ untuk tomat cherry dan $10.378,60 \mathrm{~kg}$ untuk tomat beef dalam satu greenhouse. Hasil perhitungan menunjukkan bahwa dalam satu siklus panen tomat cherry dan tomat beef total pengeluaran sebesar $\mathrm{Rp}$ 117.206.220,45 dan menghasilkan total penerimaan sebesar Rp 310.267.500 dengan harga jual yang berbeda-beda antar jenis produk. Dengan demikian, pendapatan yang diperoleh perusahaan sebesar Rp 193.061.280. Berdasarkan hasil analisis usahatani tersebut, PT Amazing Farm layak untuk terus dijalankan karena keuntungan yang diperoleh dapat menutupi biaya produksi. Tomat beef menghasilkan keuntungan yang tinggi karena grade tomat beef lebih beragam. Adanya jenis produk dengan grade yang lebih beragam diduga dapat menambah nilai keuntungan produk. Menurut Pantastico (1989), sortasi dan grading diperlukan untuk 
mendapatkan keuntungan yang memadai sesuai dengan mutu barang.

\section{KESIMPULAN}

Kegiatan penelitian di PT Amazing Farm meningkatkan kemampuan teknis dan manajemen penulis, sehingga dapat menjadi ilmu tambahan untuk dunia kerja. Pemanenan tomat tidak dapat dilakukan sekaligus, tetapi harus dilakukan berkali-kali sesuai dengan kematangan tomat. Produksi tomat mencapai $50 \%$ pada panen ke-19 dari total 39 kali panen untuk tomat cherry dan panen ke-17 dari total 44 kali panen untuk tomat beef. Produksi tomat cherry mampu mencapai $2.262,20 \mathrm{~g}$ dan tomat beef $4.752,53 \mathrm{~g}$ per tanaman. Secara umum, masa panen awal tomat menghasilkan bobot panen yang lebih besar dibandingkan masa panen akhir.

Hal ini terbukti dengan bobot rata-rata panen tomat cherry tertinggi diperoleh saat panen ke-6 dan bobot rata-rata panen tomat beef tertinggi diperoleh saat panen ke-12. Masa panen juga akan mempengaruhi kualitas buah. Semakin bertambah umur panen, semakin menurun bobot tomat dan mutu tomat terutama pada akhir masa panen. Produksi tomat di perusahaan ini layak untuk terus dijalankan karena keuntungan yang diperoleh dapat menutupi biaya produksi.

\section{DAFTAR PUSTAKA}

[Dirjen Hortikultura] Direktorat Jenderal Holtikultura. 2010. Produksi tanaman sayuran di Indonesia tahun 2007. Internet] [diunduh 2017 Juli 31] tersedia pada www.hortikultura. deptan.go.id.

[Dirjen Hortikultura] Direktorat Jenderal Holtikultura. 2015. Statistik produksi hortikultura tahun 2014. Internet] [diunduh 2017 Desember 20] tersedia pada www.hortikultura.pertanian.go.id.

[FAO] Food and Agriculture Organization. 2010. Nutrition and food system division. [Internet] [diunduh 2017 Agustus 28] tersedia pada www.fao.org.

Harun, R.M. 1989. Potential productivity of hydroponically-grown tomatoes in the genting highlands, Malaysia. J. Pertanika 12(3): 293-298.

Indriasti, R. 2013. Analisis usaha sayuran hidroponik pada PT Kebun Sayur Segar
Kabupaten Bogor. Skripsi. Institut Pertanian Bogor. Bogor.

[Kementan] Kementrian Pertanian. 2012. Daftar keputusan Menteri Pertanian. Internet] [diunduh 2017 Desember 20] tersedia pada www.deptan.go.id.

Lingga, P. 1999. Hidroponik Bercocok Tanam Tanpa Tanah. Penebar Swadaya, Jakarta.

Pantastico, E. B. 1989. Fisiologi pascapanen, penanganan dan pemanfaatan buahbuahan dan sayur-sayuran tropika dan subtropika. Kamaryani, penerjemah. Yogyakarta (ID): Gajah Mada University Pr. Terjemahan dari: Postharvest physiology, handling and utilization of tropical and subtropical fruits and vegetables.

Perry, K.B., Y. Wu, D.C. Sanders, J.T. Garrett, D.R. Decoteau, R.T. Nagata, R.J. Dufault, K.D. Batal, D.M. Granberry, W.J. McLaurin. 1997. Heat unit to predict tomato harvest in the southeast USA. Agriculture and Forest Meteorology 84(1):249-254.

Prabawati, W. 2011. Pengusahaan sayuran pakchoi baby dan tomat cherry di PT Saung Mirwan, Megamendung, Bogor. Skripsi. Institut Pertanian Bogor. Bogor

[Pusdatin] Pusat Data dan Sistem Informasi Pertanian. 2014. Outlook komoditi tomat. Internet] [diunduh 2017 September 18] tersedia pada www.epublikasi.setjen.pertanian.go.id.

[Pusdatin] Pusat Data dan Sistem Informasi Pertanian. 2015. Statistik lahan pertanian tahun 2010-2014. Internet] [diunduh 2017 September 15] tersedia pada www.perpustakaan.bappenas.go.id.

Putri, R. M., Adiwirman. E. Zuhry. 2014. Studi pertumbuhan dan daya hasil empat galur tomat (Lycopersicum esculentum Mill) di dataran rendah. Jom Faperta 1(2): 26-35.

Rapusas, R.S. 2006. Postharvest losses in vegetables. Dalam: Rolle R.S (Ed). Postharvest management of fruits and vegetables in the Asia-Pasific region. Asian Productivity Organization (APO), Tokyo. 
Syakur, A. 2012. Pendekatan satuan panas (heat unit) untuk penentuan fase pertumbuhan dan perkembangan tanaman tomat di dalam rumah tanaman (greenhouse). J. Agroland. 19(2): 96-101 .
Wijayani, A., W. Widodo. 2005. Usaha meningkatkan kualitas beberapa varietas tomat dengan sistem budidaya hidroponik. J. Ilmu Pertanian 12(1): 7783. 